\title{
A TERÜLETI ÁRRENDSZEREK ÉS FOGYASZTÁSI SZERKEZETEK ELTÉRÉSE ÉS A GAZDASÁGI TEVÉKENYSÉG SZINTJÉNEK ÖSSZEHASONLÍTHATÓSÁGA
}

\author{
(The Differences in Spatial Price Systems and Consumption \\ Structure and the Comparability of the Level of Economic \\ Activities)
}

\section{DUSEK TAMÁS}

Egy ország gazdasági teljesítményének regionális szintủ nyomon követése, valamint az országok teljesítményének egymáshoz képesti alakulása a gazdaságpolitikai döntéshozók, a közgazdászok és a széles közvélemény érdeklödésére is számot tarthat. Jelen tanulmány a gazdasági tevékenységek szintjének területi összehasonlítása során fellépö nehézségek két sajátos elemével foglalkozik. A területi árrendszerek (az egyes termékeknek a vizsgált területen érvényesülő relatív árainak összességét), valamint az egyes területek eltérő fogyasztási szerkezetének vizsgálata során a gazdaság minőségi különbségeit tárhatjuk fel. Ezek a különbségek ugyanakkor közvetve a mennyiségi eltérésekröl is árulkodnak. Az ilyen összehasonlítások statisztikai módszertana természetesen régóta kidolgozott, de most nem a statisztikai szempontokat kívánjuk tárgyalni, hanem elsősorban a statisztikai módszereket alátámasztó gazdaságelméleti megfontolások felöl közelítjük meg a témát.

Mielőtt a nehézségek mibenlétére rátérnénk, azt mutatjuk be, hogy milyen értelemben problémamentesek a mennyiségi összehasonlítások. Két vagy több területegységen végzett termelés és a rendelkezésre álló jövedelem folyó árakon történő egyértelmủ összehasonlításához három feltételnek kell teljesülnie:

1) Tartalmilag azonos felépítésủ a gazdasági tevékenységek számbavételi rendszere.

2) Nincsenek a gazdasági tevékenységekkel kapcsolatos területi lehatárolási problémák.

3) Ugyanazt a pénzt használják.

Ez a három feltétel szükséges és egyben elégséges a folyó áras adatok összehasonlításához. A harmadik feltétel egyben magában foglalja azt a követelményt, hogy a területegységek gazdasági szereplöi közvetlenül vagy közvetett módon kapcsolatban álljanak egymással. Két egymástól teljesen elszigetelt gazdaságot csak naturális mutatók alapján lehetne összehasonlítani. Gyakorlatilag a második és a harmadik feltétel komplementer viszonyban van egymással, vagyis országos egységeknél kisebb területeknél nincsen pénzügyi probléma, de nagyok a lehatárolási nehézségek, országok között pedig a lehatárolási probléma elhanyagolható mértékü, a pénzuigyi viszont nem. 
Az előző három feltétel teljesülése esetén a mérés elméletileg rendkívül egyszerüen történik. Az egyes területek gazdálkodói (GDP) illetve lakosai (GNI) által realizált pénzjövedelmeket kell egymással összeadni. Az egyes termékek területileg eltéró relatív árarányai nem zavarják az összehasonlítást, mivel az áruk pénzben kifejezett csereértékének változásai a szubjektív értékelmélet szerint egyuitt járnak a jószágok értékváltozásával (Hayek 1995; Mises 1980). Az sem zavar minket, hogy az árrendszer a szabályozás következtében ismeretlen mértékben tér el a szabályozás nélküli állapothoz képest. A szabályozás indítékai gyakran gazdaságon kívüliek, vélt vagy valós társadalmi igény fejeződik ki bennük. Azért nem szükséges jelen esetben ezzel a kérdéssel foglalkozni, mert a fogyasztót szuverénnek tételezzük fel, aki képes mérlegelni a választási lehetỏségei között, a fogyasztói árakat veszi figyelembe és nem egyéb képzetes cserearányokat, a társadalmi igazságosságról szőtt magasztos és egyben zavaros célokat pedig tetszés szerint beépítheti a döntéshozatali indokai közé.

Az eddig leírtakból kiderül, hogy valójában a folyóáras összehasonlítások elméletileg problémamentesen végezhetők el. Országon belüli területi összehasonlításoknál többnyire folyóáras adatokat használnak a statisztikai hivatalok és a kutatók, nemzetközi összehasonlításoknál viszont három további módszer is ismert, melyek a statisztikai adatok elérhetősége esetén használhatók lennének regionális (országon belüli) összehasonlításoknál is. Összesen tehát a következő négy módszer létezik:

1) A nemzeti (regionális) mutatók átszámítása közös pénzegységre a hivatalos árfolyam valamilyen átlagával. Közös pénz használata esetén vagy országon belül az árfolyam 1:1-hez lesz.

2) A nemzeti (regionális) mutatók átszámítása közös pénzegységre képzetes árfolyamon (,vásárlóerö-paritáson”). Közös pénz használata esetén, vagy országon belül az árfolyam csak akkor lesz 1:1-hez, ha a kiválasztott termékekért fizetendő pénzmennyiség a két területegység esetén egyenlö.

3) A nemzeti (regionális) mutatók alkotórészeinek azonos árrendszerrel való átárazása. Ez lehet a bázisterület árrendszere vagy képzetes árrendszer. A változatlan áras értékindexek használatának mind a területi, mind az idöbeli indexek számításánál két indoka van. Az első indok szerint az országok (régiók) eltérỏ árszínvonala, illetve két idöpont eltérö relatív árai követelik meg a változatlan áras számításokat ${ }^{1}$. Ebben az esetben a térbeliség illetve időbeliség bekapcsolásából adódó problémákat paradox módon a térbeliség illetve időbeliség kikapcsolásával oldjuk meg. A második indok már komolyabb: az árfolyamok hektikus mozgása a térbeliség esetén és a nem árualapú pénz mennyiségének korlátlan növelhetősége, vagyis az infláció lehetősége az idó esetén. Az árfolyamváltozás problémája (sok egyéb pénzïgyi probléma mellett) automatikusan megszünik közös pénz használata esetén.

4) Fizikai indikátorok alapján következtetés a gazdasági tevékenység szintjére.

A módszerek sorrendje megegyezik gazdaságelméleti alátámasztottságuk sorrendjével. Különösen a második és a harmadik módszer között létezik egy erős 
választóvonal, mert az első kettő módszert igazolja a különféle gazdasági javak termelését és fogyasztását a határköltségek és határhasznok összevetésére alapító gazdasági kalkuláció (Bacon-Beckerman 1966).

Az ENSZ által 1968 óta végzett összehasonlítások a szubjektív értékelmélettel teljesen összeegyeztethetetlen harmadik módszer szerint készülnek ${ }^{2}$. Ez az eljárás eltekint attól, hogy a jószágok szükségletkielégítési képességének egyetlen objektív méröszáma a piacon kialakult ár (Hayek 1976), és hogy teljesen természetes és az eltérő helyi termelési és fogyasztási feltételek és szokások miatt szükséges is az egyes termékek területileg és időbelileg különbözö relatív árainak létezése.

Az eddig elmondottak összefoglalásaként megállapítható, hogy két terület gazdasági tevékenysége színvonalának összehasonlítása közös pénz használata esetén ellentmondásmentesen valósítható meg, amennyiben a csereértékek összességét szeretnénk megtudni, vagyis az egyes módszer segítségével. Nem közös pénz használatakor a pénzek cserearányainak megállapítása nem állapítható meg egzakt módon. Az összes többi módszer használatánál szembetaláljuk magunkat azzal az általános problémával, hogy a minőségileg különböző objektumok mennyiségi összehasonlíthatósága bizonyos korlátokba ütközik ${ }^{3}$.

Most térünk rá azokra a nehézségekre, amelyek szükebb értelemben tartoznak a címben felvetett kérdéshez. A hátralevő részben azt vizsgáljuk meg, hogy az egyes területi árrendszerek és a fogyasztási szerkezetek mennyiben térnek el egymástól. Ha lehet kvantifikálni az eltérések mértékét, akkor a területegységek gazdasága közötti minőségi különbségekre kapunk egy számot. Ezzel a számmal egyrészt mérni tudjuk, hogy a területegységek kettes és hármas módszerrel történö összehasonlítása során mekkora a súlyok és az árak megválasztásának az eredményre gyakorolt hatása. Másrészt ettöl függetlenül is értékes információt kapunk a területegységek gazdasági távolságáról. Minél nagyobb a különbség két terület között, annál nehezebben lehet az életszínvonalukat egymással összehasonlítani.

A folyó áras adatok bár megmutatják a termelés és jövedelem területi eltéréseit, az életszínvonalra legfeljebb csak utalnak, mert az emberek számára mindig a helyi árarányok a relevánsak életszínvonaluk szempontjából. Vagyis ha egy kecskeméti asztalos jövedelme csak tizedakkora, mint passaui kollégájáé, és emellett tizedakkora lakhatási költségekkel, ötödakkora élelmiszerárakkal és hasonló fogyasztási cikk árakkal kell számolnia, akkor életszínvonaláról annyit állapíthatunk meg biztosan, hogy az nem tízedakkora lesz passaui kollégájánál.

Kettő gyakorlati példán keresztül világítjuk meg ezeknek a vizsgálatoknak a hasznát. Képzeljük el a következő országláncolatokat: Izland-Norvégia-Dánia-Hollandia-Ausztria-Olaszország-Görögország-Ciprus-Egyiptom-Szudán-Kenya, valamint Svájc-Ausztria-Magyarország-Románia-Moldova ${ }^{4}$. Az első esetben a közvetlenül egymás mellett álló országokról az az intuitív megérzésünk lehet, hogy a köztük lévő földrajzi eltérések nem gátolják az összehasonlítást, a távolság növekedésével azonban egyre kevésbé érezzük hasonlónak a természetföldrajzi adottságokat. Országon belül is találkozunk rendkívül nagy földrajzi különbségekkel, például 
Chilében az Atacama-sivatagtól az Andokon át a Tủzföldig meglehetősen eltérő éghajlati viszonyok uralkodnak. A második sorozatnál a földrajzi szomszédság és a kicsi területi kiterjedés ellenére a közvetlen szomszédokról is érezhetjük úgy, hogy nehezen összehasonlíthatók. Kérdés, hogy intuíciónkat mennyire tudjuk egzakt módon alátámasztani.

Az alapproblémát a következőkben lehet vázolni. A gazdaságban százezres nagyságrendủ fogyasztási cikk és szolgáltatás cserél gazdát milliárdnyi csereaktus segítségével. Ezeknek az aktusoknak a nyilvántartása fizikailag lehetetlen. Szükséges kiválasztani egyes termékeket és szolgáltatásokat és ezeknek néhány csereaktusát ahhoz, hogy egyáltalán az árrendszerről és a termékszerkezetről számszerủen tudjunk mondani valamit. A valóság ezen leegyszerüsítési folyamatának öt lépcsőjét lehet elkülöníteni:

1) A reprezentatív termékek kiválasztása.

2) A technikailag azonos termékek beazonosítása.

3) A termék megfigyelési pontok kiválasztása.

4) A termék megfigyelési időpontok kiválasztása, az időbeli árváltozások kezelése.

5) Az átlagszámítás módszere.

A termék reprezentativitása azt jelenti, hogy a kiválasztott termék nemcsak önmagát képviseli, hanem egy árucsoportot. Gondot jelent, hogy ami az egyik területen reprezentatív terméknek minősülhet a fogyasztási szerkezetben betöltött szerepe alapján, az a másikban esetleg elö sem fordul.

A technikailag azonos termékek beazonosításának módja már érdekesebb probléma, mind régión belül, mind régiók között. Ez a lépés a valóságban döntő jelentöségủ, ugyanakkor az elemzéshez mégis szükséges leegyszerüsítése, hiszen szigorúan szólva csak akkor tekinthetỏ két technológiai értelemben azonos termék gazdasági értelemben is azonosnak, hogyha a tér ugyanazon pontján, ugyanabban az időpontban vált a csere révén fogyasztási cikké, mert a jószágok térpozíciója hatással van csereértékükre (Mises 1980). Ehhez az elméleti megkötéshez járulnak azok a gyakorlati jellegủ nehézségek, mint a minőségi, méretbeli, csomagolási, fizetési kedvezménybeli, kiegészítỏ szolgáltatásbeli és egyéb különbségek, melyeket mind kezelni szükséges.

A megfigyelési pontok kiválasztási módja szintén érzékenyen befolyásolhatja az eredményeket. A település-hierarchia mentén és a boltok típusai szerint is jelentős árkülönbségeket tapasztalhatunk.

Ezzel rátérnénk a megfigyelési időpontok kérdésére. A termékek időbeli árváltozásának az okai között elméletileg különbséget tehetünk:

- ciklikus és nem ciklikus árváltozások, valamint

- termék oldalról illetve pénz oldalról bekövetkezett árváltozások között.

A ciklikus árváltozások alapvetỏen lehetnek napi, heti, havi és éves rendszerességủek. Az ennél hosszabb ciklikusnak mondható változások jelen elemzés keretei közül kicsúsznak. Különös a jelentőségük az éves ciklusoknak a mezögazdasági termények és szezonális árucikkek árváltozásaiban. Az egy év alatt 
egyenletesen elfogyasztott paradicsom értéke különbözni fog a néhány hónap alatt elfogyasztott ugyanakkora mennyiségtől. Akár néhány termék ciklikus árváltozása is befolyást gyakorol az összes többi termék relatív árára.

A termék oldalról indult árváltozást a termék relatív szükösségének a változása okozza. Ez lehet szezonális eredetú is, de ennél fontosabbak az egyedi események következtében fellépő változások, mint például egyes bányakincsek természeti okok vagy versenykorlátozás miatt fokozódó relatív szủkössége, mint az történt például az olajárrobbanás során. Ennek ellenkezője is elképzelhető új lelőhelyek feltárásával, új termelési eljárások kifejlesztésével.

Ezek a ciklikus és egyedi árváltozások az egyes területi árrendszerekben nem feltétlenül azonos időpontokban játszódnak le. A különbözö időszakok területi átlagárai így lényegesen különbözhetnek egymástól. Az áruk idődimenziója olykor elhanyagolható, olykor viszont lényeges szerepet játszik a területközi cserearányok alakulásában. Nyilvánvalóan ennek jelentősége a vizsgálandó időszakaszra jutó árváltozások nagyságától függ.

Végül az átlagárak kiszámítása következik, amivel kicsit részletesebben foglalkozunk. Az összehasonlítások végzéséhez egyetlen áradatra van szükség, vagyis a kijelölt területi aggregációs szinten belüli árkülönbségektől el kell tekinteni. Ezzel külsőleg homogén egységek jönnek létre.

Induljunk ki az l. táblázatban látható számadatokból. A területegység két régióra oszlik, amelyen belül árkülönbségek csupán az árusítás helye szerint léteznek. Az 1. régióban fogyasztják a termék $80 \%$-át, a másikban a maradék $20 \%$-ot.

\section{TÁBLÁZAT}

Egy termék ára és fogyasztott mennyisége két régióban elárusitóhelyek szerint (Price and Consumed Quantity of a Given Product in Two Regions at the Place of Sale)

\begin{tabular}{lcccc}
\hline & \multicolumn{2}{c}{ 1. régió } & \multicolumn{2}{c}{ 2. régió } \\
\cline { 2 - 5 } & $a$ ár & súly (\%) & ár & súly (\%) \\
\hline Városi bolt & 100 & 40 & 110 & 10 \\
Városi diszkont & 80 & 30 & 80 & 10 \\
Városi piac & 60 & 10 & 70 & 30 \\
Utcai árus & 50 & 10 & 60 & 20 \\
Falusi piac & 40 & 10 & 35 & 30 \\
\hline
\end{tabular}

Forrás: Saját számítás a Handbook of the international comparison programme (1992) alapján.

A két régióra és a teljes területre többféle átlagárat számolhatunk ki. A 2. táblázatban néhány lehetőség szerint elvégzett számítás eredményét mutatjuk be. Bár ennél a 16 féle módszernél jóval több létezik (hiszen helyzeti középértékeket is lehet számolni), de ha csupán kétféle módszer létezne, az is elég lenne a nem egyértelmü eredményhez. 
Dusek Tamás: A területi árrendszerek és fogyasztási szerkezetek eltérése és a gazdasági tevékenység szintjének összehasonlíthatósága.

Tér és Társadalom, 14. 2000. 2-3. 129-137. p.

134 Dusek Tamás

TÉT XIV. évf. $2000 \square 2-3$

\section{TÁBLÁZAT}

Egy termék átlagára különféle számitások szerint

(Average Price of a Given Product by Different Calculations)

\begin{tabular}{llllcccc}
\hline & & \multicolumn{5}{c}{ átlagárak } \\
\cline { 3 - 8 } & & 1. régió & 2. régió & \multicolumn{2}{c}{ országos számtani } & \multicolumn{2}{c}{ országos mértani } \\
\cline { 5 - 8 } számtani & & & & súlyozatlanozatlan & súlyozott & súlyozatlan & súlyozott \\
& súlyozott & 66,0 & 71,0 & 68,5 & 67,0 & 68,5 & 67,0 \\
\multirow{3}{*}{ mértani } & 79,0 & 62,5 & 70,8 & 75,7 & 70,3 & 75,4 \\
& súlyozatlan & 62,6 & 66,4 & 64,5 & 63,4 & 64,5 & 63,3 \\
& súlyozott & 75,7 & 58,5 & 67,1 & 72,2 & 66,5 & 71,9 \\
\hline
\end{tabular}

Forrás: Saját számítás.

A gyakorlatban ráadásul nem rendelkezünk a számpéldához hasonlóan teljes körủ adatokkal. A súlyokat csak becsülni lehet, mivel az ország néhány pontján, és akkor is csak időszakosan folyik a megfigyelés.

Miután a fenti lépéseken túljutottunk, a 3. táblázathoz hasonló listával fogunk rendelkezni. A tárgyalandó mutatók értékeit ezen példa alapján számoljuk ki és mutatjuk be.

\section{TÁBLÁZAT}

Az egyes termékek fogyasztási szerkezetben betöltött súlya és ára (The Share of Different Products in the Consumption Structure and Their Prices)

\begin{tabular}{ccccccc}
\hline \multirow{2}{*}{ Termék jele } & \multicolumn{2}{c}{ A termékböl fogyasztott mennyiség \% } & \multicolumn{3}{c}{ A termék ára } \\
\cline { 2 - 7 } & A terület & B terület & C terület & A terület & B terület & C terület \\
\hline 1 & 25 & 22 & 25 & 100 & 2 & 20 \\
2 & 15 & 20 & 15 & 140 & 2 & 20 \\
3 & 15 & 20 & 16 & 150 & 2 & 18 \\
4 & 20 & 20 & 0 & 30 & 2 & - \\
5 & 5 & 10 & 0 & 50 & 3 & - \\
6 & 15 & 0 & 20 & 200 & - & 25 \\
7 & 5 & 5 & 0 & 300 & 4 & - \\
8 & 0 & 0 & 24 & - & - & 20 \\
9 & 0 & 3 & 0 & - & 8 & - \\
\hline
\end{tabular}

Forrás: Saját számítás.

$\mathrm{Az}$ egyes területek alatt tetszés szerinti területi egységeket érthetünk, az egyik véglet a városrész, a másik az országok egy csoportja. Az országos szintnek gyakorlati szempontból van csupán kitüntetett jelentősége, mivel az adatok hozzáférhetősége a statisztikai adatgyüjtés rendszere miatt többnyire országos szintü. Ennél 
kisebb területi egységre általában külön felmérést kellene végezni, mivel nincsenek vagy nem elégséges mennyiségủek a statisztikai adatok.

$\mathrm{Az}$ alább ismertetendő mutatók nem speciálisan a termékszerkezeti és árkülönbségek számszerú jellemzésére lettek megalkotva, hanem más területekröl is ismertek. Egy részük csak a termékszerkezetbeli különbségeknél használható. Az elsö és legegyszerübb mutatót az amerikai Mudgett professzor javasolta (Drechsler 1966) az összehasonlíthatóság fokának mérésére:

$$
\frac{N_{A}+N_{B}-2 N_{A B}}{N_{A}+N_{B}}
$$

ahol

$N_{A}$ az A területegység fogyasztási szerkezetében előforduló termékek száma,

$N_{B}$ a $B$ területegység fogyasztási szerkezetében elöforduló termékek száma,

$\mathrm{N}_{\mathrm{AB}}$ mindkét területegység fogyasztási szerkezetében előforduló termékek száma.

Teljes egynemüség esetén a mutató értéke 0 , teljes különbözőségnél $100 \%$. A mutató előnye az egyszerüsége, az adatok könnyủ elérhetősége. Hátránya, hogy az egyes termékeket nem különbözteti meg eltérő súlyuk szerint.

A 2. táblázat adatai alapján A és B között értéke 14\%, A és C között 43\%, és B és C között is $43 \%$, vagyis legközelebb A és B fogyasztási szerkezete áll egymáshoz.

A területi egyenlötlenségek mérésénél gyakran használt mutatószám a Hooverindex, ezt most mi is felhasználhatjuk céljainkhoz:

$$
H=\frac{\sum\left|A_{i}-B_{i}\right|}{2}
$$

ahol ebben az esetben

$A_{i}$ az egyes fogyasztási cikkek részesedése az összes fogyasztásból A területegységen, $B_{i}$ az egyes fogyasztási cikkek részesedése az összes fogyasztásból B területegységen.

Vagyis az eredeti Hoover-indexhez képest itt a területek szerepét az árucikkek veszik át, a két összehasonlítandó jellemzöt pedig a két területegységgel cseréltük fel. Mudgett professzor javasolta mutatót ez alapján nevezhetnénk súlyozatlan módosított Hoover-indexnek. Az index értéke teljesen azonos fogyasztási cikk szerinti összetétel esetén éri el minimális 0 értékét, a teljes különbözőséget jelentő maximális $100 \%$-ot pedig akkor, ha egyetlen azonos terméket sem fogyasztanak a két országban. A 2. táblázat alapján A és B között a legkisebb a különbség (18\%), A és C között közepes (30\%), B és C között pedig a legnagyobb (47\%).

A további mutatókat egyedi termékekre bontott szerkezeti elemzésre csak akkor lehet felhasználni, ha mindegyik termék szerepel mindkét ország fogyasztásában, mert különben 0 érték kerül a nevezöbe és értelmezhetetlenné válik. Ezért gyakorlatilag ezeket inkább csak termékcsoportoknál lehet használni. 
A szóródási együtthatót a fogyasztási szerkezetek és az árarányok különbségének a jellemzésére is használhatjuk:

$v_{q_{1}}$ a termékmennyiségek hányadosainak relatív szórása $q_{0}$

$\mathcal{V}_{p_{1}}$ a termékárak hányadosainak relativ szórása $p_{0}$

Értékük minél nagyobb, annál jobban különböznek egymástól a területegységek a két jellemző szerint.

Végủl az utolsó mutató a kủlönféle bázissal számolt indexek közötti eltérés révén ad tájékoztatást a teruiletek összehasonlíthatóságának mértékéröl:

$$
\frac{\sum q_{1} p_{1}}{\sum q_{0} p_{1}} / \frac{\sum q_{1} p_{0}}{\sum q_{0} p_{0}}
$$

Ennek a mutatónak az az elönye, hogy egyszerre jelenik meg benne a fogyasztási szerkezet és az árszerkezet eltérése. A Bortkiewitz által feltárt összefüggés szerint (Drechsler 1966) a mutató nagysága egyenlő lesz a következő kifejezéssel:

$$
1+\left[\frac{v_{p_{1}}}{v_{p_{0}}} * \frac{v_{q_{1}}}{v_{q_{0}}} * r\left(\frac{p_{1}}{p_{0}} \frac{q_{1}}{q_{0}}\right)\right]
$$

ahol $r\left(\frac{p_{1}}{p_{0}} \frac{q_{1}}{q_{0}}\right)$ a termékárak hányadosai és a termékmennyiségek hányadosai közötti korreláció mértéke.

Mindegyik mutató hasznos információkat szolgáltat arról, hogy két területegység közötti mennyiségi és értékadatok összehasonlításának mekkora a realitási foka. A végpontokat leszámítva egyik mutatónak sincs olyan határvonala, ami alatt már egyáltalán ne lehetne összehasonlítani a területeket. Inkább két összehasonlítást tudunk segítségükkel egymáshoz viszonyítani. Ha például azt kapjuk, hogy Izland és Ciprus fogyasztási szerkezete között a Hoover-index értéke 70\%, Ausztria és Moldova között pedig 60\%, akkor ez utóbbi két országot még nagyobb megbízhatósággal lehet ősszehasonlítani, mint az elsö kettőt.

\section{Jegyzetek}

${ }^{1}$ Részletesebb leírást tartalmaz például Ehrlich Éva: Országok versenye 1937-1986 c. könyve.

${ }^{2}$ Az eljárás leirását lásd Handbook of the international comparison programme c. müben.

${ }^{3}$ Jánossy könyvében (A gazdasági fejlettség mérheb̈sége és új mérési módszere) részletesen foglalkozik a minöségileg különbözỏ objektumok mennyiségi összehasonlíthatóságának kérdésével.

${ }^{4}$ Lásd még Drechsler László: Értékbeni mutatószámok nemzetközi összehasonlításának módszertana c. múvét. 


\section{Irodalom}

A GDP (bruttó hazai termék) nemzetközi összehasonlítása 1993. (1996) Budapest, KSH.

Bacon, R.-Beckerman, W. (1966) International Comparisons of income levels: a suggested new measure. - The Economic Journal 3. 519-536. o.

Drechsler L. (1966) Értékbeni mutatószámok nemzetközi összehasonlitásának módszertana. Budapest, Közgazdasági és Jogi Könyvkiadó.

Ehrlich É. (1991) Országok versenye 1937-1986. Budapest, Közgazdasági és Jogi Könyvkiadó.

Gilbert, M. (1958) Comparative national products and price levels. Párizs, OECD.

Handbook of the international comparison programme. (1992) New York, United Nations.

Hayek, F.A. von (1976) Preise und Produktion. Wien.

Hayek, F.A. von (1995) Intertemporális áregyensúly és a pénzérték ingadozásai. Piac és szabadság. Budapest, Közgazdasági és Jogi Könyvkiadó.

Jánossy F. (1963) A gazdasági fejlettség mérhetốsége és új mérési módszere. Budapest, Közgazdasági ês Jogi Könyvkiadó.

Kurabayashi, Y.-Sakuma, I. (1990) Studies in international comparisons of real product and prices. Tokyo, Kinokuniya Company Ltd.

Mises, L. von (1980) The theory of money and credit. Indianapolis, Liberty Classics.

\section{THE DIFFERENCES IN SPATIAL PRICE SYSTEMS AND CONSUMPTION STRUCTURE AND THE COMPARABILITY OF THE LEVEL OF ECONOMIC ACTIVITIES}

\section{TAMÁS DUSEK}

Interregional comparison of the economic performance is very interesting for the economists, the decision-makers and also for the public. This study deals with two special elements of comparison which usually cause many problems. The first one is the examination of spatial price systems (relative prices of individual products in a given region). And the second is the research of the qualitative differences between the consumption structures of individual regions. Statistical methodology of comparisons has been elaborated on for a long time so we won't like to deal with the different statistical viewpoints, rather approach the theme from the economic theoretical considerations which support these methods. 